\title{
Calcareous nannofossils from the Upper Cretaceous of northern James Ross Island, Antarctica: a pilot study
}

\author{
Lilian ŠVÁBENICKÁ, Radek VODRÁŽKA and Daniel NÝVLT
}

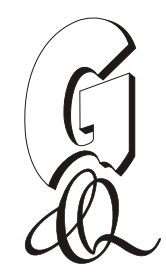

Švábenická L., Vodrážka R. and Nývlt D. (2012) - Calcareous nannofossils from the Upper Cretaceous of northern James Ross Island, Antarctica: a pilot study. Geol. Quart., 56 (4): 765-772, doi: 10.7306/gq.1053

The Czech scientific expedition to northern James Ross Island, Antarctica has tested the use of calcareous nannofossils as a possible tool for stratigraphic correlation of Cretaceous and Neogene strata. Only a few samples with poor nannofossil content gave useful information for biostratigraphy. The Lower Campanian Chiastozygus garrisonii Zone and Gephyrobiscutum diabolum Subzone, respectively, was established in the lower part of the Santa Marta Formation, Lachman Crags Member, from the common occurrence of Gephyrobiscutum diabolum associated with Broinsonia parca parca and Acuturris scotus. Deposits of the Late Miocene Mendel Formation yielded exclusively reworked nannofossils from the older Upper Cretaceous deposits. Nannofossils indicate at least two distinct stratigraphic levels: Middle Coniacian and Santonian-basal Campanian, and these must have been sourced from the immediate area. The majority of the marine deposit samples studied were barren of nannofossils, probably due to late diagenetic secondary decalcification.

Lilian Švábenická and Radek Vodrážka, Czech Geological Survey, Klárov 131/3, 11821 Praha, Czech Republic, e-mails: lilian.svabenicka@geology.cz,radek.vodrazka@geology.cz; Daniel Nývlt,Czech Geological Survey, Brno Branch, Leitnerova 22, 65869 Brno, Czech Republic, e-mail: daniel.nyvlt@ geology.cz (received: April 25, 2012; accepted: June 13, 2012; first published online: September 27, 2012).

Key words: Antarctica, James Ross Island, Upper Cretaceous, calcareous nannofossils, biostratigraphy.

\section{INTRODUCTION}

During geological research and mapping by the Czech scientific expeditions to the northern James Ross Island that focused on the immediate area surrounding the Johann Gregor Mendel Czech Antarctic Station situated at about 63⒋" S (Fig. 1), attention was paid to the stratigraphic interpretation of Upper Cretaceous and Upper Miocene strata. As the biostratigraphy of this region has been based on palynomorphs and macrofossils (bivalves, ammonites), the aim of this study was to investigate the presence of calcareous nannofossils in the various lithologies and to validate their biostratigraphic significance.

Although most of the deposits studied did not contain any nannofossils, a few samples provided relevant information from both the biostratigraphical and palaeoecological points of view. Given the scarce published data on calcareous nannofossils of the James Ross Basin carried out mainly by Argentine specialists from the University of Buenos Aires, the results of this study represent an important contribution to the knowledge of this area.

\section{GEOLOGICAL SETTING}

Both Lower and Upper Cretaceous strata of the Gustav and Marambio groups (James Ross Basin) are exposed in the mapping area (Fig. 1). In most of the area studied they are overlain by Cenozoic lavas and hyaloclaste breccias (James Ross Island Volcanic Group), and also by the Cenozoic Mendel, Hobbs Glacier and Cockburn Island formations (Nývlt et al., 2011; Pirrie et al., 2011) and Quaternary deposits.

The stratigraphy of the Upper Cretaceous strata of northern James Ross Island has been studied by many authors (e.g., Ineson et al., 1986; Olivero et al., 1986; Pirrie, 1989; Rinaldi, 1992). The Gustav Group of northern James Ross Island comprises the following formations: (1) Kotick Point Formation, characterized by interbedded sandstones and silty mudstones or claystones; (2) Whisky Bay Formation, dominated by coarse-grained deposits, although mudstone- and sandstone-dominated intervals also occur (Ineson et al., 1986). The transition between the Whisky Bay Formation and the overlying (3) Hidden Lake Formation essentially represents the start 

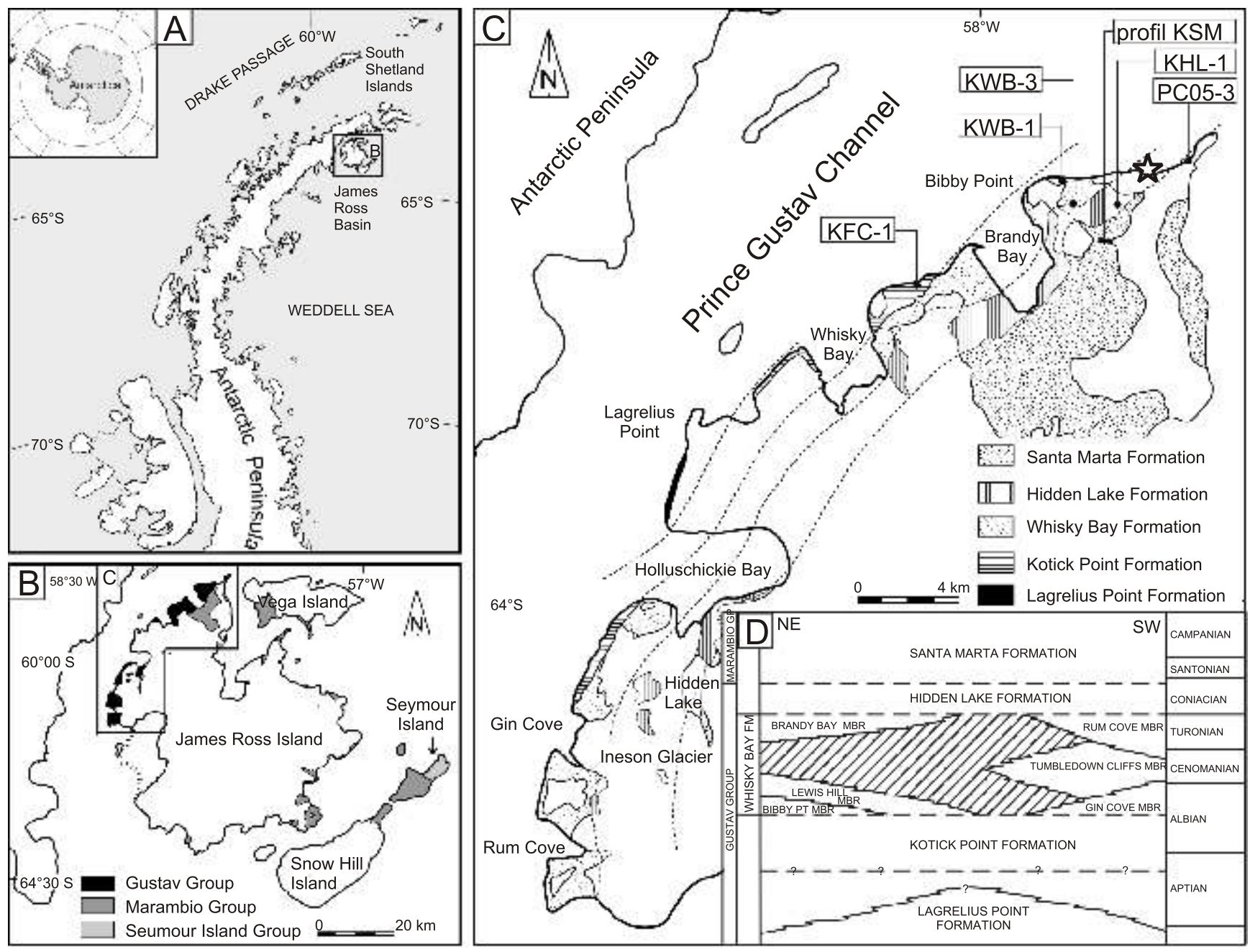

Fig. 1A - map showing the location of the James Ross Island region; B - geological sketch map of the Gustav, Marambio and Seymour Island groups in the James Ross Island region, based on Crame and Luther (1997); C - geological sketch map showing Cretaceous deposits of northwestern James Ross Island with positions of section and samples tested for the presence of nannofossils. The dashed lines show formation boundaries across sea and ice cover. Based on Ineson et al. (1986). Star indicates the position of the Johann Gregor Mendel Czech Antarctic Station; D stratigraphic correlation diagram for Cretaceous deposits of northwestern James Ross Island (based on Crame et al., 2006). For geographical location of these sediments see Figure $1 \mathrm{C}$

of a fining-upwards cycle from the conglomerate-dominated Whisky Bay Formation to the sandstone-dominated Hidden Lake Formation (Whitham et al., 2006). The general fining-upwards trend through the Hidden Lake Formation reflects a decreasing supply of coarse volcanic detritus to the basin, with a progressive decrease in water depth (Pirrie et al., 1992).

The Marambio Group of northern James Ross Island comprises the Santa Marta Formation that was originally defined by Olivero et al. (1986) and subdivided into three members: Alpha, Beta and Gamma. Crame et al. (1991) redefined the Santa Marta Formation and combined the Alpha and Beta members into the Lachman Crags Member. The samples studied (Figs. 1 and 2) belong to the lower-middle part of the Lachman Crags Member (Alpha Member of Olivero et al., 1986). These strata have been interpreted to have been deposited within a mid- to outer-shelf below storm wave base (Pirrie, 1989).

Comparative samples (Fig. 1 and Table 1) were gathered from the basal terrestrial glacigenic deposits (subglacial melt-out tills and lodgement tills) of the Mendel Formation (Nývlt et al., 2011). The Mendel Formation (max. thickness of
$80 \mathrm{~m}$ ) was formed between 5.9 to $5.4 \mathrm{Ma}$ and is represented by glacigenic, glaciomarine and marine sediments deposited during two Late Miocene glacioeustatic cycles (Nývlt et al., 2011). The basal strata of the Mendel Formation overlie volcanic rocks of the James Ross Island Volcanic Group and the Upper Cretaceous Hidden Lake and Santa Marta formations (Fig. 1).

\section{PREVIOUS BIOSTRATIGRAPHIC STUDIES}

Early biostratigraphic studies focused primarily on the well-preserved molluscan faunas, especially bivalves and ammonites (e.g., Crame, 1981; Olivero, 1981). Subsequent studies of microfossils from the James Ross Island region have clearly shown the potential for establishing biostratigraphic frameworks using foraminifera, diatoms, silicoflagellates and palynomorphs (e.g., Askin, 1988; Harwood, 1988; Huber, 1988). Other preliminary studies on James Ross and surrounding islands have also shown the potential of palynomorphs for local and regional biostratigraphical correlation (e.g., Askin, 


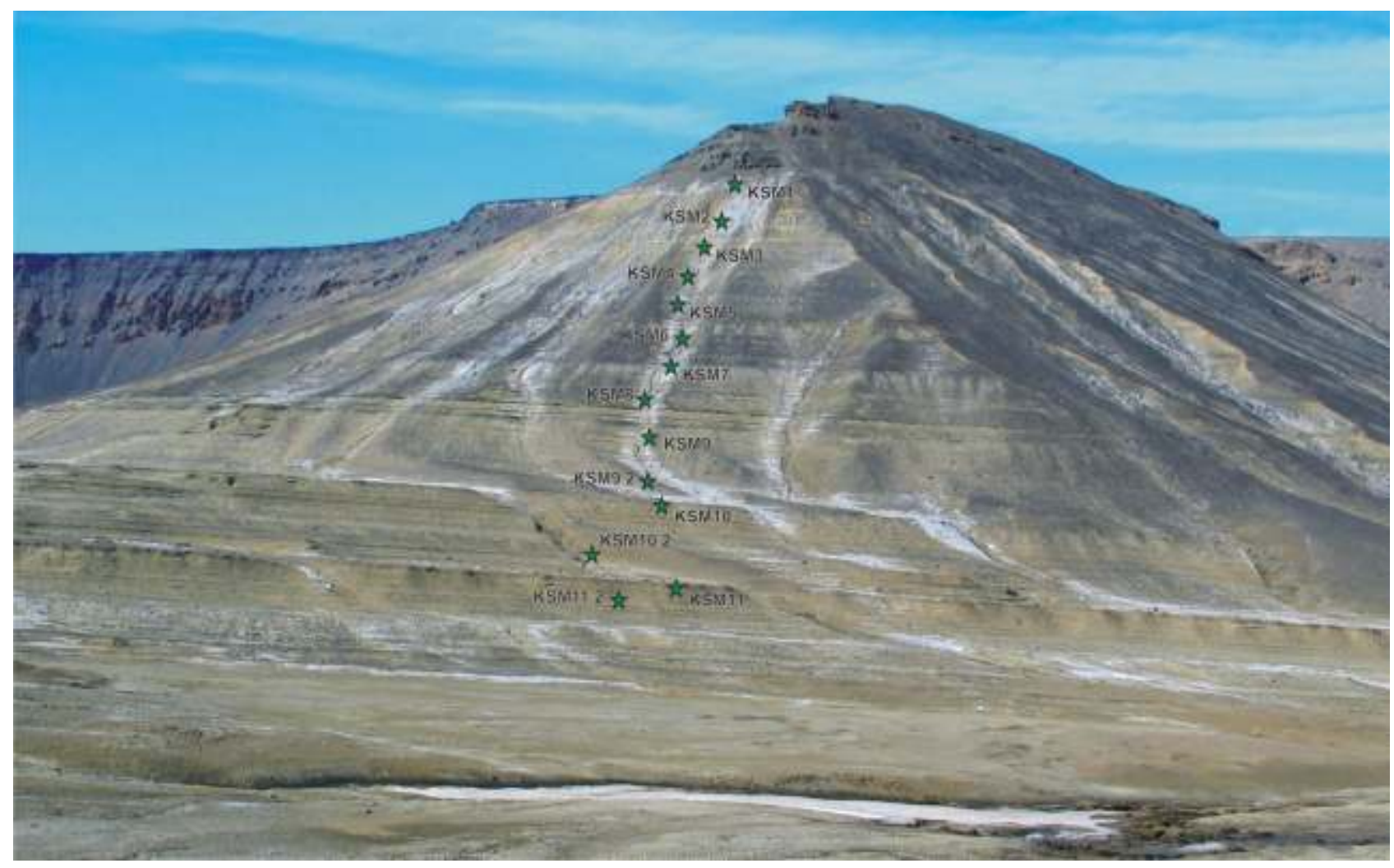

Fig. 2. Slope of Lachman Crags, viewed from the Crame Col (northern James Ross Island), formed by Upper Cretaceous siltstones (Lachman Crags Member, Santa Marta Formation) capped by Neogene basaltic lavas and hyaloclaste breccia

All samples gathered from this section are marked on the photograph, although, except for KSM 4 and KSM 5, the samples provided no calcareous nannofossils; for more detailed localization of samples see Table 1

Lithostratigraphy, GPS coordinates and abundance (occurrence) of calcareous nannofossils from the samples studied

\begin{tabular}{|c|c|c|c|c|c|}
\hline Sample no. & Formation, Member & $\begin{array}{c}\text { WGS } \\
\mathrm{S}\end{array}$ & $\begin{array}{c}\text { WGS } \\
\mathrm{W}\end{array}$ & $\begin{array}{c}\text { Altitude } \\
{[\mathrm{m}]}\end{array}$ & $\begin{array}{c}\text { Nannofossils } \\
\text { abundance }\end{array}$ \\
\hline KSM 1 & Santa Marta, Lachman Crags & $63^{\circ} 49^{\prime} 46.5^{\prime \prime}$ & $57^{\circ} 53^{\prime} 11.1^{\prime \prime}$ & 285 & - \\
\hline KSM 2 & Santa Marta, Lachman Crags & $63^{\circ} 49^{\prime} 46.4^{\prime \prime}$ & $57^{\circ} 53^{\prime} 12.3^{\prime \prime}$ & 274 & - \\
\hline KSM 3 & Santa Marta, Lachman Crags & $63^{\circ} 49^{\prime} 46.1^{\prime \prime}$ & $57^{\circ} 53^{\prime} 13.6^{\prime \prime}$ & 264 & - \\
\hline KSM 4 & Santa Marta, Lachman Crags & $63^{\circ} 49^{\prime} 46.0^{\prime \prime}$ & $57^{\circ} 53^{\prime} 14.8^{\prime \prime}$ & 254 & +++ \\
\hline KSM 5 & Santa Marta, Lachman Crags & $63^{\circ} 49^{\prime} 45.7^{\prime \prime}$ & $57^{\circ} 53^{\prime} 16.1^{\prime \prime}$ & 244 & + \\
\hline KSM 6 & Santa Marta, Lachman Crags & $63^{\circ} 49^{\prime} 45.7^{\prime \prime}$ & $57^{\circ} 53^{\prime} 18.4^{\prime \prime}$ & 234 & - \\
\hline KSM 7 & Santa Marta, Lachman Crags & $63^{\circ} 49^{\prime} 45.6^{\prime \prime}$ & $57^{\circ} 53^{\prime} 20.3^{\prime \prime}$ & 224 & - \\
\hline KSM 8 & Santa Marta, Lachman Crags & $63^{\circ} 49^{\prime} 45.2^{\prime \prime}$ & $57^{\circ} 53^{\prime} 22.7^{\prime \prime}$ & 214 & - \\
\hline KSM 9 & Santa Marta, Lachman Crags & $63^{\circ} 49^{\prime} 45.2^{\prime \prime}$ & $57^{\circ} 53^{\prime} 24.5^{\prime \prime}$ & 204 & - \\
\hline KSM 9.2 & Santa Marta. Lachman Crags & $63^{\circ} 49^{\prime} 44.7^{\prime \prime}$ & $57^{\circ} 53^{\prime} 27.6^{\prime \prime}$ & 197 & - \\
\hline KSM 10 & Santa Marta. Lachman Crags & $63^{\circ} 49^{\prime} 44.9^{\prime \prime}$ & $57^{\circ} 53^{\prime} 29.1^{\prime \prime}$ & 194 & - \\
\hline KSM 10.2 & Santa Marta. Lachman Crags & $63^{\circ} 49^{\prime} 43.5^{\prime \prime}$ & $57^{\circ} 53^{\prime} 32.7^{\prime \prime}$ & 189 & - \\
\hline KSM 11 & Santa Marta. Lachman Crags & $63^{\circ} 49^{\prime} 44.5^{\prime \prime}$ & $57^{\circ} 53^{\prime} 34.8^{\prime \prime}$ & 184 & - \\
\hline KSM 11.2 & Santa Marta. Lachman Crags & $63^{\circ} 49^{\prime} 44.2^{\prime \prime}$ & $57^{\circ} 53^{\prime} 35.4^{\prime \prime}$ & 181 & - \\
\hline KHL-1 & Hidden Lake & $63^{\circ} 48^{\prime} 51.4^{\prime \prime}$ & $57^{\circ} 52^{\prime} 56.1^{\prime \prime}$ & 72 & - \\
\hline KWB-1 & Whisky Bay. Lewis Hill & $63^{\circ} 48^{\prime} 56.8^{\prime \prime}$ & $57^{\circ} 54^{\prime} 55.0^{\prime \prime}$ & 121 & - \\
\hline KWB-3 & Whisky Bay. Brandy Bay & $63^{\circ} 48^{\prime} 12.8^{\prime \prime}$ & $57^{\circ} 55^{\prime} 30.8^{\prime \prime}$ & 62 & - \\
\hline KFC-1 & Kotick Point & $63^{\circ} 51^{\prime} 10.1^{\prime \prime}$ & $58^{\circ} 04^{\prime} 52.9^{\prime \prime}$ & 31 & - \\
\hline PC05-3 & Mendel & $63^{\circ} 47^{\prime} 34.3^{\prime \prime}$ & $57^{\circ} 48^{\prime} 39.7^{\prime \prime}$ & 3 & +++ \\
\hline
\end{tabular}


1983; Olivero and Palamarczuk, 1987; Baldoni and Medina, 1989; Keating, 1992; Keating et al., 1992; Riding et al., 1992; Riding and Crame, 2002).

Cretaceous nannofossils from the Antarctic area including the Falkland Plateau are mentioned by Wind (1979), Huber et al. (1983), Thomas et al. (1990), Wei and Thierstein (1991), Watkins et al. (1996) and Lees (2002). These studies focused not only on stratigraphic interpretations but also on latitudinal changes in nannoplankton assemblages and on the distribution of cosmopolitan, high-latitude and endemic species. Upper Cretaceous nannofossils and their biostratigraphic interpretation from the James Ross Basin have been studied in particular by Argentinian (Concheyro et al., 1991; Robles Hurtado and Concheyro, 1995) and North American palaeontologists (Kulhanek, 2007).

\section{MATERIAL AND METHODS}

Material for nannofossil study was collected from localities at walking distance from the Johann Gregor Mendel Czech Antarctic Station in the 2004 and 2005 field seasons. Samples were collected from the Kotick Point (sample KFC-1), Whisky Bay (samples KWB-1 and KWB-3), Hidden Lake (sample KHL-1) and Santa Marta (KSM section samples) formations (Figs. 1, 2 and Table 1). Concerning precise sample location, sample KSM 11 (see Fig. 2) was gathered from the level of a prominent concretion horizon, which is $90 \mathrm{~m}$ above the base of the Santa Marta Formation (Pirrie, 1987). Positive samples KSM 5 and KSM 4 correspond to levels of 150 and $160 \mathrm{~m}$ above the base of the Santa Marta Formation respectively. Further samples (PC05 section, see Fig. 1) were obtained from the recently described Late Miocene Mendel Formation (Nývlt et al., 2011). Nannofossil smear-slides are stored in the collections of the Czech Geological Survey, Prague. Rock samples are deposited in the Czech Geological Survey, Prague.

Nannofossils were investigated in the $2-30 \mu \mathrm{m}$ fraction by a decantation method using $7 \%$ solution of $\mathrm{H}_{2} \mathrm{O}_{2}$. The coarse fraction was allowed to settle for 3 minutes in a $45 \mathrm{~mm}$ water column and removed; the fine fraction was saved for slide preparation after 45 minutes. Simple smear-slides were mounted using Canada Balsam and inspected at 1000× magnification, using an oil-immersion objective on a Nikon Microphot-FXA transmitting light microscope. Biostratigraphic data were interpreted using the zonation for the Upper Cretaceous of the Southern Ocean by Watkins et al. (1996).

\section{RESULTS}

\section{SANTA MARTA FORMATION}

Calcareous nannofossils were present in two of 14 samples taken from the KSM section (Fig. 2 and Table 1), in samples KSM 4 and KSM 5.

KSM 4

The smear-slide contained predominantly inorganic material. Calcareous nannofossils (ca. 1-5 specimens per one field of view of the microscope) formed a minimal proportion of the fraction and the preservation is very poor. Small placoliths (ca. 2-4 $\mathrm{m}$ ) of Gephyrobiscutum diabolum (small, placoliths extended along the longer axis, ca. 1-2 specimens per one field of view of the microscope; Fig. 3A1-A4) predominate; other nannofossils are scarce and preserved mostly as fragments. This assemblage contains low numbers of stratigraphically significant species such as Acuturris scotus (one specimen), Broinsonia parca parca, Eiffellithus eximius, Broinsonia cf. dentata, Lucianorhabdus maleformis-quadrifidus and L. ex gr. cayeuxii (two specimens; Fig. 3). Specimens of the genus Prediscosphaera are small in proportion, including miniature specimens ( $2 \mu \mathrm{m}$ ) resembling P. bukryi (Fig. 3J). These species are accompanied by Eiffellithus turriseiffelii (two specimens), Ahmuellerella octoradiata, Arkhangelskiella cymbiformis ("large" and broadly elliptical placoliths with a relatively narrow outer rim), Biscutum ellipticum, Biscutum magnum (one fragment), Broinsonia enormis, Calculites ovalis, Cribrosphaerella ehrenbergii (one specimen), Cyclagelosphaera rotaclypeata, Gartnerago obliquum, Kamptnerius magnificus, Prediscosphaera cretacea, P. spinosa, Reinhardtites anthophorus, Rhagodiscus angustus, Tranolithus orionatus, Thoracosphaera sp., Vekshinella aachena (sensu Watkins et al., 1996), Watznaueria barnesiae (four specimens), Zeugrhabdotus scutula, Z. trivectis, and Z. diplogrammus.

The sample also provided "cubes" of questionable origin that are comparable with those found for example in the Bohemian Cretaceous Basin (Švábenická, 2012).

KSM 5

A smear-slide containing calcareous material of inorganic origin and scarce nannofossils (ca. 1 specimen per 10 fields of view of the microscope) of extremely poor preservation. The following taxa were identified: Biscutum sp., Gephyrobiscutum sp., Staurolithites laffitei, Prediscosphaera sp.

Samples taken from the Kotick Point Formation (KFC-1), Whisky Bay Formation (KWB-1, KWB-3) and Hidden Lake Formation (KHL-1) provided no calcareous nannofossils.

\section{MENDEL FORMATION}

Calcareous nannofossils were present in only one of 13 samples taken from the section:

$$
\text { PC05-3 }
$$

Nannofossils form a minimal proportion of the sediment (1-2 specimens per 10 fields of view of the microscope). They are badly preserved and mostly fragmented. Strong etching is obvious especially on placoliths (the central fields are usually missing) and holococcoliths (genus Lucianorhabdus) show signs of overgrowth. Probable secondary impoverishment of the assemblage was caused by carbonate dissolution as indicated by the relatively high numbers of Watznaueria barnesiae.

The assemblage is formed of the following species (Fig. 4): Arkhangelskiella specillata, Prediscosphaera cretacea, $P$. ponticula, P. cf. grandis (sensu Burnett, 1998), Kamptnerius magnificus, Lucianorhabdus quadrifidus, L. maleformis, L. cf. inflatus (fragments), Quadrum gartneri, Q. intermedium 

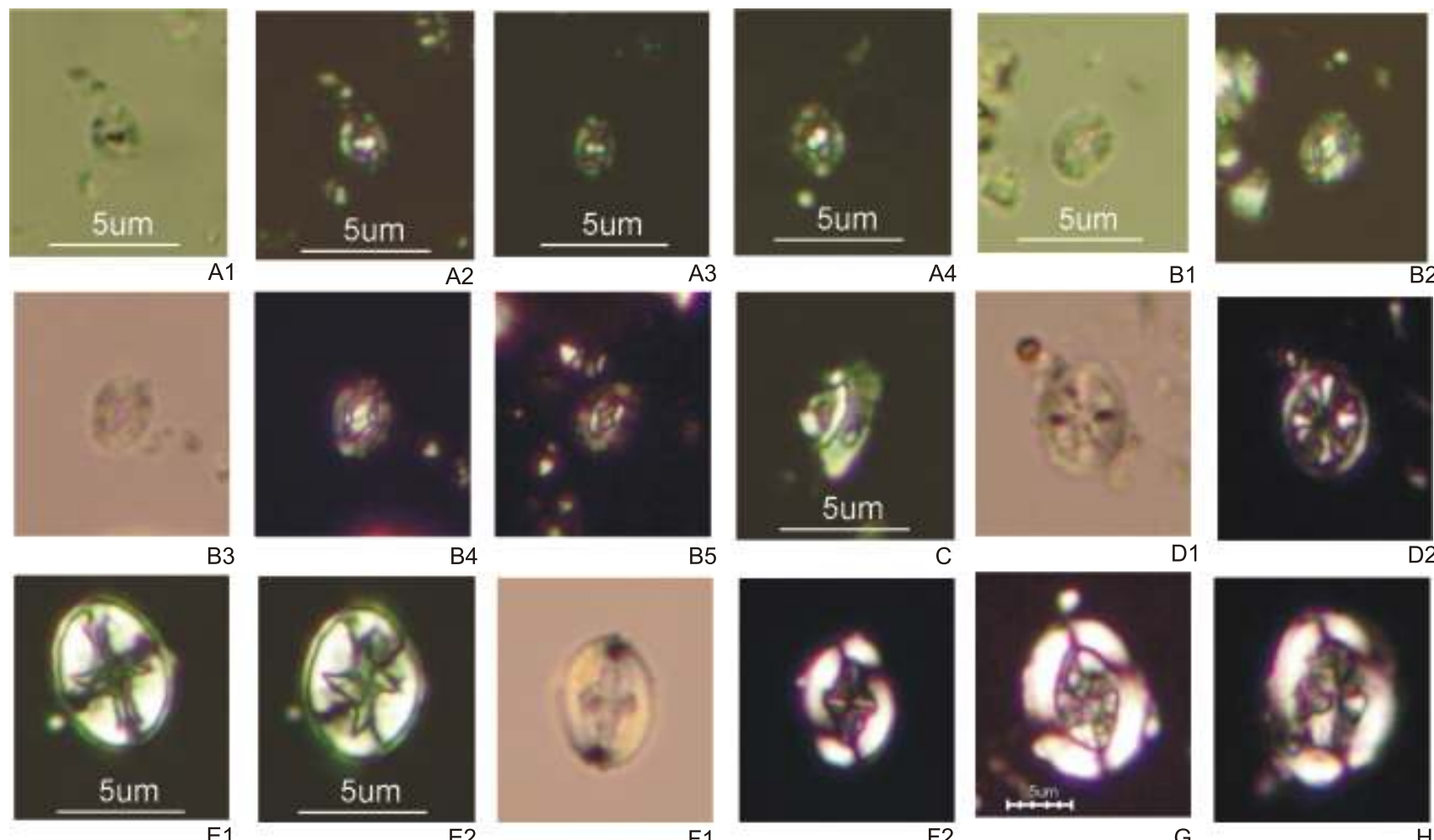

F2

E1
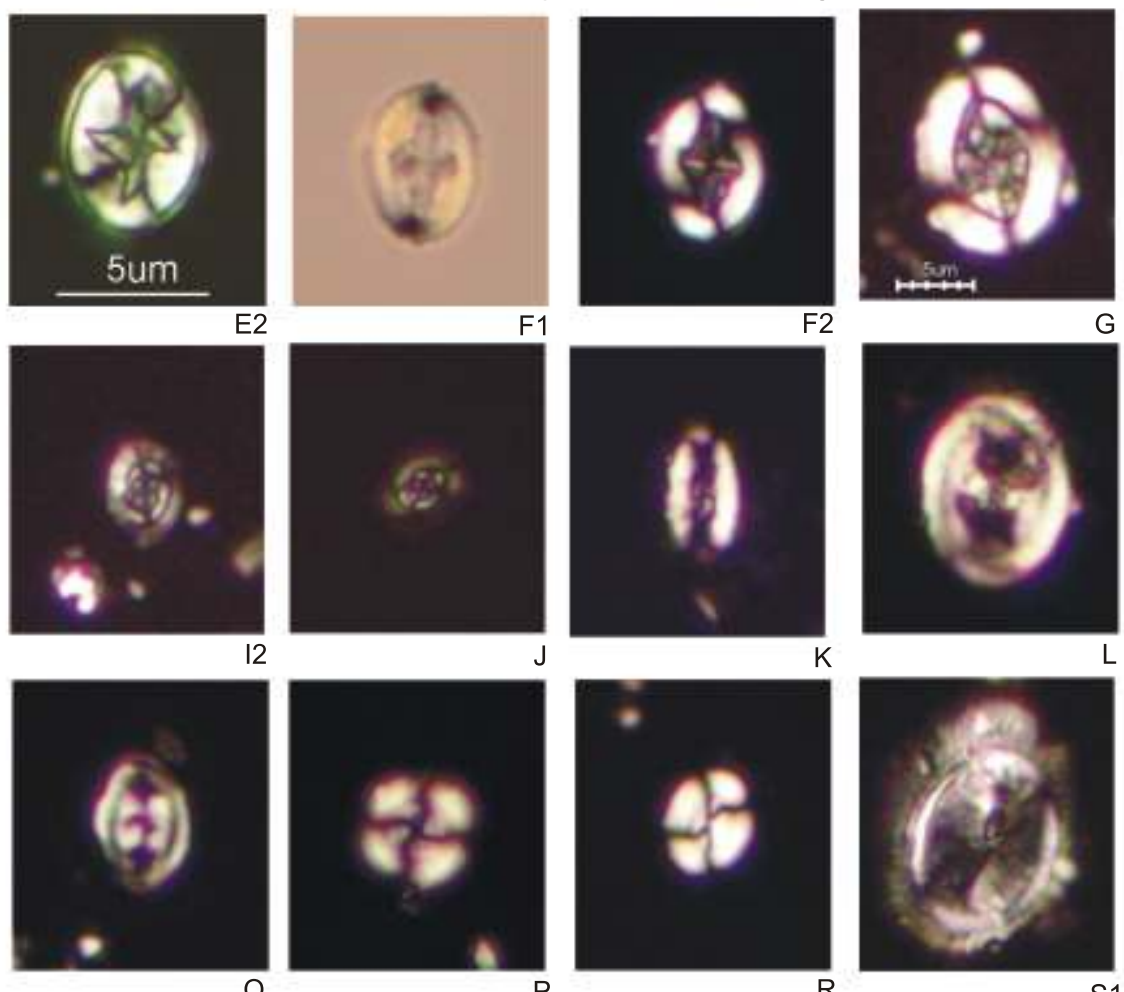

$\mathrm{R}$
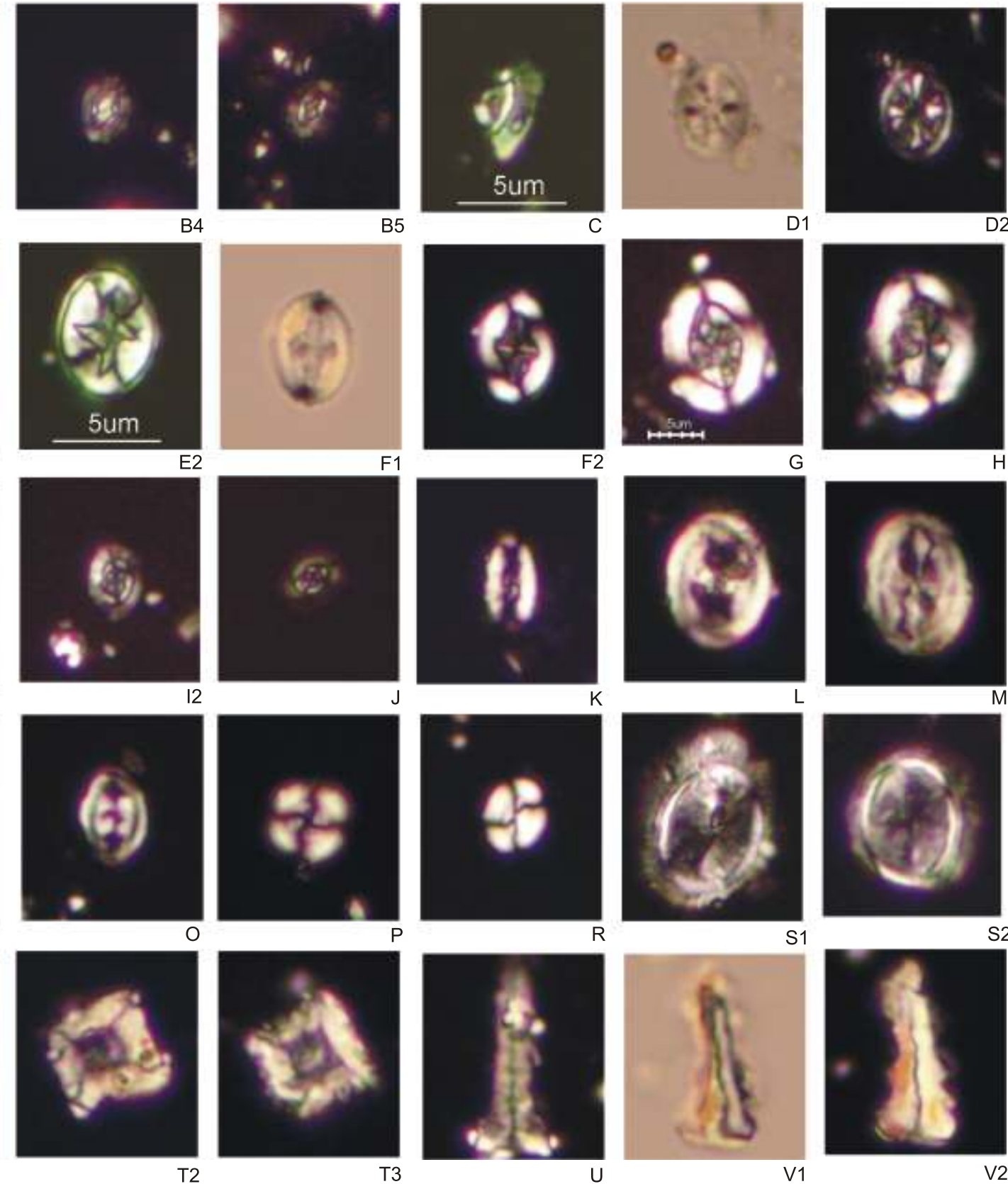

Fig. 3. Calcareous nannofossils of the Santa Marta Formation, James Ross Island, Antarctica, sample KSM 4, Lower Campanian

A1-A4 - Gephyrobiscutum diabolum, A1 - PPL, A2-A4 - XPL; B1-B5-Gephyrobiscutum cf. diabolum, B1, B3 - PPL, B2, B4, B5 - XPL; C-Biscutum magnum, fragment, XPL; D1, D2 - Ahmuelerella octoradiata, specimen in PPL and XPL; E1, E2 - Eiffellithus eximius, specimen at $0^{\circ}$ and $15^{\circ}$, XPL; F1, F2 - Broinsonia dentata, specimenn in PPL and XPL; G - Broinsonia parca parca, XPL; H - Arkhangelskiella ex gr. cymbiformis, XPL; I1, I2 Prediscosphaera cretacea, XPL; J - Prediscosphaera bukryi, XPL; K - Rhagodiscus angustus, XPL; L - Reinhardtites anthophorus, XPL; M Vekshinella aachena, XPL; N - Staurolithites laffittei, XPL; O-Tranolithus orionatus, XPL; P - Cyclagelosphaera rotaclypeata, XPL; R - Watznaueria barnesiae, XPL; S1, S2 - Kamptnerius magnificus, XPL; T1-T3 - ?Polycyclolithaceae, "cube" of questionable origin, specimen in PPL and XPL; U Acuturris scotus, XPL; V1, V2 - Lucianorhabdus ex gr. cayeuxii, specimen in PPL and XPL; PPL - plane polarized light, XPL - cross polarized light; for magnification see Figure $3 \mathrm{~A}$, if not indicated otherwise 

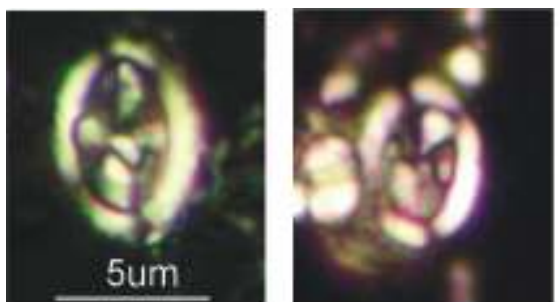

A
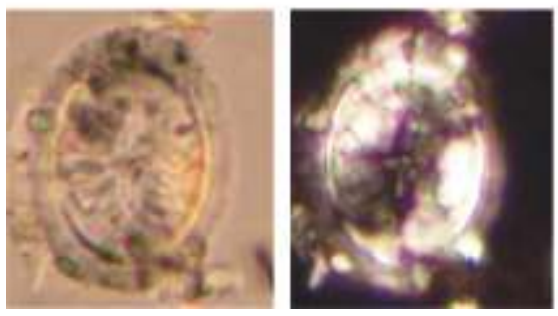

G

$\mathrm{H}$

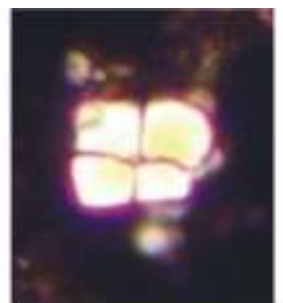

B

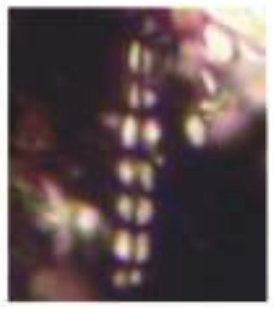

C
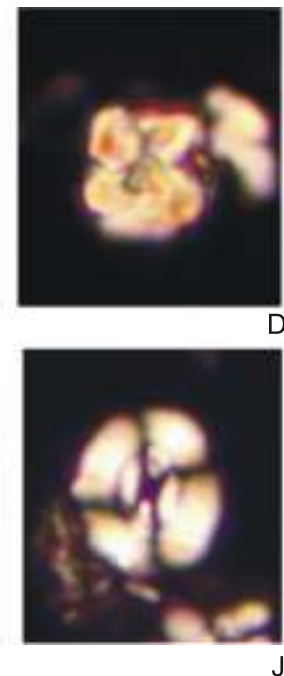

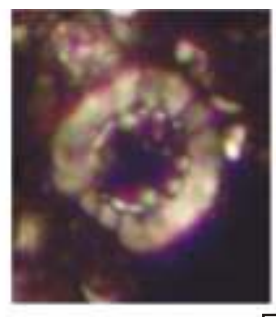

D

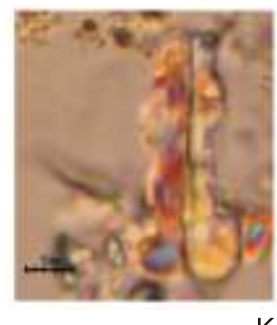

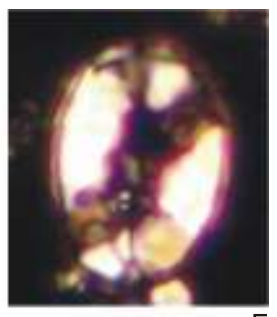

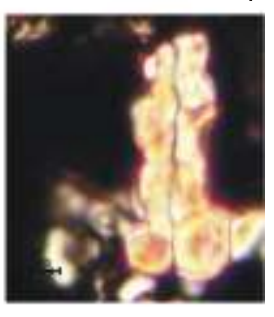

Fig. 4. Reworked calcareous nannofossils from the Upper Cretaceous strata into the glacigenic Miocene deposits of the Mendel Formation, sample PC05-3

A - Arkhangelskiella sp., XPL; B - Broinsonia enormis, XPL; C - Quadrum gartneri, XPL; D - Micula staurophora, XPL; E - Prediscosphaera sp., central area of specimen strongly corroded, XPL; F - Eiffellithus eximius, XPL; G, H - Kamptnerius magnificus, specimen in PPL and XPL; I Microrhabdulus attenuatus, XPL; J - Watznaueria barnesiae, XPL; K, L - Lucianorhabdus quadrifidus, specimen in PPL and XPL; PPL - plane polarized light, XPL - cross polarized light; for magnification see Figure 4A

(5 and 7 segments), Manivitella pemmatoidea, Microrhabdulus attenuatus, Gartnerago obliquum, Broinsonia enormis, Micula staurophora (three specimens), Eiffellithus eximius (specimen with strongly etched central field with cross), Retacapsa sp. (outer rim).

\section{DISCUSSION}

The nannofossil assemblage of the sample KSM 4 (Santa Marta Formation) documents the Lower Campanian, Chiastozygus garrisonii Zone (upper part - interval of the Gephyrobiscutum diabolum Subzone) sensu Watkins et al. (1996). This biostratigraphic interpretation concurs with the previously published biostratigraphical framework based on the molluscan macrofauna and palynomorphs (see Pirrie et al., 1992). From the palaeogeographical point of view, the sedimentary area of James Ross Island region must have had some relation to the Falkland Plateau during the Early Campanian, because both Watkins et al. (1996) and Burnett (1998) regard Gephyrobiscutum diabolum as an endemic species of the Falkland Plateau.

The nearly ubiquitous and common species Watznaueria barnesiae, in Upper Cretaceous assemblages throughout the world, was found here only in very low numbers. Wei and Thierstein (1991) mentioned its sporadic occurrence in the Maastrichtian of the Kerguelen Plateau. According to Watkins et al. (1996), W. barnesiae became sporadic and rare in high southern latitudes (e.g., the $R$. parvidentatum Subzone on the Kerguelen and Naturaliste plateaux in the Upper Campanian) and later also in lower latitudes of the Southern Hemisphere. In addition to scarce $W$. barnesiae, sample KSM 4 provided G. diabolum and its short stratigraphic range is correlated with the Lower Campanian (Watkins et al., 1996).

The sporadic occurrence of small specimens of the genus Prediscosphaera (a central cross situated along the axes of the elliptic placolith, see Fig. 3J) here mentioned as $P$. bukryi needs further material and study. $P$. bukryi is known from the Albian-Maastrichtian. Its small specimens may be easily mistaken for $P$. stoveri especially in poorly preserved material. $P$. stoveri is mentioned as a bipolar species restricted to high-latitudes. In the North Sea, its first occurrence is placed at the base the base of UC15d $\mathrm{d}^{\mathrm{BP}}$ Subzone, lower Upper Campanian (Burnett, 1998); in the Southern Hemisphere it is first noted in the Biscutum coronum Zone, upper Upper Campanian and its common occurrence in the uppermost Maastrichtian was used for definition of the Prediscosphaera stoveri Acme Subzone (Watkins et al., 1996). It is interesting that Watkins et al. (1996) did not mention any P. bukryi from older Campanian deposits and vice versa Kulhanek (2007) any P. stoveri from the Maastrichtian of the northern James Ross Basin.

The nannofossil taphocoenose found in sample PC05-3 (Mendel Formation) contains at least two types of nannofossil assemblages:

1. An assemblage with Micula staurophora and Quadrum gartneri, Middle to Upper Coniacian, UC10 Zone.

2. An assemblage with Arkhangelskiella specillata, Prediscosphaera cf. grandis and Lucianorhabdus inflatus may document the Santonian and ?probably also the lowermost Campanian. Similarly reworked Campanian-Maastrichtian nannofossil taphocoenoses were recovered by Gaździcka and Gaździcki (1994) from the Pliocene Pecten Conglomerate of Cockburn Island (about $5 \mathrm{~km}$ north-west from Seymour Island).

Nannofossils of Campanian, Maastrichtian and/or Cenozoic age have not been found. The presence of the genera Lucianorhabdus, Quadrum and Kamptnerius may reflect deposition in a shallow epicontinental sea of normal salinity. According to the summary of lithostratigraphy of the James Ross Basin (Pirrie et al., 1992), reworked nannofossils of Coniacian age most probably come from the Hidden Lake Formation and species of Santonian/?lowermost Campanian age from the lower part of the Santa Marta Formation. 
The short-distance transport of the Upper Cretaceous nannofossils rewashed into the Late Miocene Mendel Formation is shown by the fact that both the Santa Marta and Hidden Lake formations crop out in the immediate vicinity of section PC05.

The absence of calcareous nannofossils from the Kotick Point, Whisky Bay and Hidden Lake formations and in part from the Santa Marta Formation is probably caused by partial or total (?) early diagenetic decalcification of the deposits. This is also supported by sporadic findings of calcareous foraminifers in most of the samples studied and by the scarcity of calcareous invertebrate shells in the area studied. In particular, conglomerates, tuffitic sandstones and siltstones of the Kotick Point, Whisky Bay and Hidden Lake formations are almost barren of original calcitic/aragonitic shells. On the other hand, siliceous macrofossils are well-preserved (Vodrážka and Crame, 2011), suggesting that carbonate dissolution played an important role during formation of these strata.

\section{CONCLUSIONS}

A scarcity of nannofossils in the Upper Cretaceous marine strata of the James Ross Basin enabled only preliminary stratigraphic conclusions.

The Santa Marta Formation (samples KSM 4 and KSM 5) is correlated with the Lower Campanian. Nannofossils indicate the Chiastozygus garrisonii Zone (Gephyrobiscutum diabolum Subzone) sensu Watkins et al. (1996) according to the common occurrence (acme) of the species $G$. diabolum associated with Broinsonia parca parca and Acuturris scotus. Moreover, G. diabolum, an endemic species of the Falkand Plateau, indi- cates connection of this palaeoregion with this territory during the deposition of the Santa Marta Formation.

Strata of the Mendel Formation, Upper Miocene, provided only reworked nannofossils from older Upper Cretaceous deposits. Nannofossils indicate two stratigraphic levels (and probably two source areas): Middle Coniacian (Micula staurophora and Quadrum gartneri) and Santonian-basal Campanian interval (Arkhangelskiella specillata and Lucianorhabdus inflatus). Reworked Upper Cretaceous nannofossils most probably come from the Hidden Lake and Santa Marta formations. An autochthonous nannoflora was not developed in the glacigenic to marine sedimentary environment of the Late Miocene.

Most of the marine deposits studied of the Gustav and Marambio groups, James Ross Basin, were barren of nannofossils probably due to (?late) diagenetic secondary decalcification.

Acknowledgements: The work of D. Nývlt and R. Vodrážka were supported by Research and Development Project of the Ministry of Environment of the Czech Republic No. SPII 1a9/23/07 and by the project of the Czech Geological Survey No. 335400. Nannofossil study was supported by the Research Programme of the Czech Geological Survey No. MZP 0002579801. Thanks go also to scientific infrastructure of the Johann Gregor Mendel Czech Antarctic station. Suggestions and comments of M. Wagreich, University of Vienna, T. Peryt, Polish Geological Institute - National Research Institute, Warszawa, and an anonymous referee helped to improve the manuscript.

\section{REFERENCES}

ASKIN R.A. (1983) - Campanian palynomorphs from James Ross and Vega Islands, Antarctic Peninsula. Antarctic J. U.S., 18 (5): 63-64.

ASKIN R.A. (1988) - Campanian to Paleocene palynological succession of Seymour and adjacent islands, northeastern Antarctic Peninsula. GSA. Mem., 169: 131-153.

BALDONI A.M. and MEDINA F. (1989) - Fauna y microflora del Cretácico, en bahia Brandy, isla James Ross, Antártida. Ser. Cient., Inst. Antártica Chileno, 39: 43-58.

BURNETT J.A. (1998) - Upper Cretaceous. In: Calcareous Nannofossil Biostratigraphy (ed. P.R. Bown): 133-199. Cambridge University Press, Cambridge.

CONCHEYRO A., OLIVERA A., SANTILLANA S., MARENSSI S. and RINALDI C. (1991) - Nanofosiles calcareous del Cretacico superior de isla Marambia, Antarctica. Congreso Geologico Chileno, Resumes Presentados, 6: 825-828.

CRAME J.A. (1981) - Upper Cretaceous inoceramids (Bivalvia) from the James Ross Island group and their stratigraphical significance. British Antarctic Surv. Bull., 53: 29-56.

CRAME J.A. and LUTHER A. (1997) - The last inoceramid bivalves in Antarctica. Cret. Res., 18: 179-195.

CRAME J.A., PIRRIE D., RIDING J.B. and THOMSON M.R.A. (1991) Campanian-Maastrichtian (Cretaceous) stratigraphy of the James Ross Island area, Antarctica. J. Geol. Soc. London, 148: 1125-1140.
CRAME J.A., PIRRIE D. and RIDING J.B. (2006) - Mid-Cretaceous stratigraphy of the James Ross Basin, Antarctica. Geol. Soc. Spec. Publ., 258: 7-19.

GAŹDZICKA E. and GAŹDZICKI A. (1994) - Recycled Upper Cretaceous calcareous nannoplankton from the Pecten Conglomerate of Cockburn Island, Antarctica. Pol. Polar Res., 15 (1-2): 3-13.

HARWOOD D.M. (1988) - Upper Cretaceous and Lower Paleocene diatom and silicoflagelate biostratigraphy of Seymour Island, eastern Antarctic Peninsula. GSA Mem., 169: 55-129.

HUBER B.T. (1988) - Upper Campanian-Paleocene foraminifera from the James Ross Island region, Antarctic Peninsula. GSA Mem., 169: 163-252.

HUBER B.T., HARWOOD D.M. and WEBB P.N. (1983) - Upper Cretaceous microfossil biostratigraphy of Seymour Island, Antarctic Peninsula. Antarctic J. U.S., 18 (5): 72-74.

INESON J.R., CRAME J.A. and THOMSON M.R.A. (1986) Lithostratigraphy of the Cretaceous Strata of West James Ross Island, Antarctica. Cret. Res., 7 (2): 141-159.

KEATING J.M. (1992) - Palynology of the Lachman Crags Member of the Santa Marta Formation (Upper Cretaceous) of north-west James Ross Island. Antarctic Sc., 4: 293-304.

KEATING J.M., SPENCER-JONES M. and NEWHAM S. (1992) - The stratigraphical palynology of the Kotick Point and Whisky Bay formations, Gustav Group (Cretaceous), James Ross Island. Antarctic Sc., 4: 279-292. 
KULHANEK D.K. (2007) - Paleocene and Maastrichtian calcareous nannofossils from clasts in Pleistocene glaciomarine muds from the northern James Ross Basin, western Weddell Sea, Antarctica: a keystone in a Changing World. Online Proceedings of the 10th ISAES, USGS Open-File Report 2007-1047, Short Research Paper 019 (eds. A.K. Cooper, C.R. Raymond et al.).

LEES J.A. (2002) - Calcareous nannofossil biogeography illustrates palaeoclimate change in the Late Cretaceous Indian Ocean. Cret. Res., 23 (5): 537-634.

NÝVLT D., KOŠLER J., MLČOCH B., MIXA P., LISÁ L., BUBÍK M. and HENDRIKS B.W.H. (2011) - The Mendel Formation: Evidence for Late Miocene climatic cyclicity at the northern tip of the Antarctic Peninsula. Palaeogeogr. Palaeoclimatol. Palaeoecol., 299: 363-384.

OLIVERO E.B. (1981) - Esquema de zonacion de ammonites del Cretácico Superior del Grupo de Islas James Ross, Antártida. Actas del VIII Congreso Geologico Argentino, 2: 897-907.

OLIVERO E.B., SCASSO R.A. and RINALDI C.A. (1986) - Revision of the Marambio Group, James Ross Island, Antarctica. Instituto Antártico Argentino Contribución, 331: 29.

OLIVERO E.B. and PALAMARCZUK S. (1987) - Amonites y dinoflagelados Cenomanianos de la isla James Ross, Antártida. Ameghiniana, 24: 35-49.

PIRRIE D. (1987) - Orientated calcareous concretions from James Ross Island, Antarctica. Br. Antarct. Surv. Bull., 75: 41-50.

PIRRIE D. (1989) - Shallow marine sedimentation within an active margin basin, James Ross Island, Antarctica. Sedim. Geol., 63: 61-82.

PIRRIE D., DUANE A.M. and RIDING J.B. (1992) - Jurassic-Tertiary stratigraphy and palynology of the James Ross Basin: review and introduction. Antarctic Sc., 4 (3): 259-266.

PIRRIE D., JONKERS H.A., SMELLIE J.L., CRAME J.A. and McARTHUR J.M. (2011) - Reworked late Neogene Austrochlamys anderssoni (Mollusca: Bivalvia) from northern James Ross Island, Antarctica. Antarctic Sc., 23 (2): 180-187.

RIDING J.B. and CRAME J.A. (2002) - Aptian to Coniacian (Early-Late Cretaceous) palynostratigraphy of the Gustav Group, James Ross Basin, Antarctica. Cret. Res., 23: 739-760.

RIDING J.B., KEATING J.M., SNAPE M.G., NEWHAM S. and PIRRIE D. (1992) - Preliminary Jurassic and Cretaceous dinoflagelate cyst stratigraphy of the James Ross Island area, Antarctic Peninsula. Newslett. Stratigr., 26 (1): 19-39.

RINALDI C.A. (1992) - Geologia de la Isla James Ross. Instituto Antarctico Argentino, Direccion Nacional del Antarctico. Buenos Aires.

ROBLES HURTADO G.M. and CONCHEYRO A. (1995) Sedimentologia y bio-cronoestratigrafia (nannofosiles calcareos) del Nunatak Sanctuary Cliffs (Cretacico Superior), Isla Cerro Nevado, Antarctica. VI Congreso Argentino de Paleontologia y Bioestragrafia, Actas: 231-237.

ŠVÁBENICKÁ L. (2012) - Nannofossil record across the Cenomanian-Coniacian interval in the Bohemian Cretaceous Basin and Tethyan foreland basins (Outer Western Carpathians), Czech Republic. Geol. Carpath., 63 (3): 201-217.

THOMAS E., BARRERA E., HAMILTON N., HUBER B.T., KENNETT J.P., O'CONNELL S.B., POSPICHAL J.J., SPIEFL V., STOTT L.D., WEI W. and WISE Jr. S.W. (1990) - Upper Cretaceous-Paleogene stratigraphy of Sites 689 and 690, Maud Rise (Antarctica). Proc. ODP, Sc. Res., 113: 901-914.

VODRÁŽKA R. and CRAME A. (2011) - First fossil sponge from Antarctica and its palaeobiogeographical significance. J. Paleont., 85 (1): 48-57.

WATKINS D.K., WISE S.W., POSPICHAL J.J. and CRUX J. (1996) - Upper Cretaceous calcareous nannofossil biostratigraphy and paleoceanography of the Southern Ocean. In: Microfossils and Oceanic Environments (eds. A. Moguilevsky and R. Whatley): 355-381. Proc. "ODP and the Marine Biosphere" International Conference, Aberystwyth 1994.

WHITHAM A.G., INESON J.R. and PIRRIE D. (2006) - Marine volcaniclastics of the Hidden Lake Formation (Coniacian) of James Ross Island, Antarctica: an enigmatic element in the history of a back-arc basin. Geol. Soc. Spec. Publ., 258: 21-47.

WEI W. and THIERSTEIN H.R. (1991) - Upper Cretaceous and Cenozoic calcareous nannofossils of the Kerguelen Plateau (Southern Indian Ocean) and Prydz Bay (East Antarctica). Proc. ODP, Sc. Res., 119: 467-493.

WIND F.H. (1979) - Maestrichtian-Campanian nannofloral provinces of the southern Atlantic and Indian Oceans. In: Deep Drilling Results in the Atlantic Ocean: Continental Margins and Paleoenvironmen (eds. M. Talwani, W.W. Hay and W.B.F. Ryan): 123-137. American Geophysical Union, Washington DC.

\section{APPENDIX}

List of calcareous nannofossils mentioned in the text, in alphabetical order of genera.

Acuturris scotus (Risatti, 1973) Wind and Wise in Wise and Wind, 1977

Ahmuellerella octoradiata (Górka, 1957) Reinhardt, 1966

Arkkhangelskiella cymbiformis Vekshina, 1959

Arkhangelskiella specillata Vekshina, 1959

Biscutum ellipticum (Górka, 1957) Grün in Grün and Alleman, 1975

Biscutum magnum Wind and Wise in Wise and Wind, 1977

Broinsonia dentata Bukry, 1969

Broinsonia enormis (Shumenko, 1968) Manivit, 1971

Broinsonia parca (Stradner, 1963) Bukry, 1969 ssp. parca

Calculites ovalis (Stradner, 1963) Prins and Sissingh in Sissingh, 1977

Cribrosphaerella ehrenbergii (Arkhangelsky, 1912) Deflandre in Piveteau, 1952

Cyclagelosphaera rotaclypeata Bukry, 1969

Eiffellithus eximius (Stover, 1966) Perch-Nielsen, 1968

Eiffellithus turriseiffelii (Deflandre in Deflandre and Fert, 1954) Reinhardt, 1965

Gartnerago obliquum (Stradner, 1963) Noël, 1970

Gephyrobiscutum diabolum Wise, 1988

Kamptnerius magnificus Deflandre, 1959

Lucianorhabdus cayeuxii Deflandre, 1959

Lucianorhabdus inflatus Perch-Nielsen and Feinberg in Perch-Nielsen, 1986

Lucianorhabdus maleformis Reinhardt, 1966
Lucianorhabdus quadrificus Forchheimer, 1972

Manivitella pemmatoidea (Deflandre in Manivit, 1965) Thierstein, 1971

Micula staurophora (Gardet, 1955) Stradner, 1963

Microrhabdulus attenuatus (Deflandre, 1959) Deflandre, 1963

Prediscosphaera bukryi Perch-Nielsen, 1973

Prediscosphaera cretacea (Arkhangelsky, 1912) Gartner, 1968

Prediscosphaera grandis Perch-Nielsen, 1979

Prediscosphaera ponticula (Bukry, 1969) Perch-Nielsen, 1984

Prediscosphaera spinosa (Bramlette and Martini, 1964) Gartner, 1968

Prediscosphaera stoveri (Perch-Nielsen, 1968) Shafik and Stradner, 1971

Quadrum gartneri Prins and Perch-Nielsen in Manivit et al., 1977

Quadrum intermedium Varol, 1992

Reinhardtites anthophorus (Deflandre, 1959) Perch-Nielsen, 1968

Rhagodiscus angustus (Stradner, 1963) Reinhardt, 1971

Staurolithites laffittei Caratini, 1963

Tranolithus orionatus (Reinhardt, 1966a) Reinhardt, 1966b

Vekshinella aachena (Bukry) Shafik and Stradner, 1971

Watznaueria barnesiae (Black, 1959) Perch-Nielsen, 1968

Zeugrhabdothus diplogrammus (Deflandre in Derflandre and Fert, 1954)

Burnett in Gale et al., 1996

Zeugrhabdotus scutula (Bergen, 1994) Rutledge and Bown, 1996

Zeugrhabdothus trivectis Bergen, 1994 